\title{
Transition to federal health and education governance
}

Laura Bolton

IDS

28 June 2021

\section{Question}

What evidence tells about the transition from centralised to federal responsibilities for education and health? What lessons have been learned in the countries that gone through the transition?

\section{Contents}
1. Summary
2. Federal decentralisation
3. Nepal
4. Indonesia
5. References

The K4D helpdesk service provides brief summaries of current research, evidence, and lessons learned. Helpdesk reports are not rigorous or systematic reviews; they are intended to provide an introduction to the most important evidence related to a research question. They draw on a rapid deskbased review of published literature and consultation with subject specialists. other Government departments, but the views and opinions expressed do not necessarily reflect those of FCDO, the UK Government, K4D or any other contributing organisation. For further information, please contact helpdesk@k4d.info. 


\section{Summary}

This report looks at transition from central to federal responsibilities for health and education in Nepal and Indonesia. Federalism is a complex process and it was outside of the scope of this review to investigate the extent to which it has been developed in these countries and the nature of its functioning.

Challenges identified in the literature on transition to federalism and decentralisation include:

- Ensuring equitable distribution of finances and resources across states.

- Slow transfer of power and lack of coordination between government levels.

- Lack of capacity at local levels and incoherence in capacity building.

- Ensuring continuity of medical supplies and continuity of health services during transition.

- Training local level health personnel in procurement.

Recommendations from experience on transition to decentralisation include:

- A clear legislative framework should be put in place.

- A slowly phased transition is needed to allow for changes and adjustments to be made.

- Conditional grants could be considered to ensure that health is not de-prioritised in a federal system.

- A communication strategy should be in place with a designated central Ministry office for oversight of the transition.

- Nepal had a Federalism and Education Support Group set up by the United Nations Educational, Scientific and Cultural Organization which may be helpful for other countries considering transition.

- Restructuring in education needs to consider multilingual, multicultural and multi-ethnic background of students.

- Consideration of a national framework for federal-level governments to interpret.

\section{Federal decentralisation}

Decentralisation in this report focusses on devolution of authority to regional government. The aim of this report is to focus on federal- or provincial level decentralisation rather than district- or village-level (Bossert \& Beauvais, 2002). However, this distinction was often not clear in the literature.

Nepal transitioned to a federal structure with legislation in 2015 so seemed a useful example. However, Nepal was not transitioning from a strictly centralised system as decentralisation of health and education had been happening prior to this date.

The extent and nature of federalism is important in transferring lessons for other countries but was outside the scope of this rapid review. Limited investigation into federalism highlights that it is a highly complex process and so is difficult to draw lessons across different contexts. Federalism alone warrants further exploration than was possible for this report.

A rapid search on the transition to federal government for health and education in Malaysia was also conducted as another country in transition, but little was found. Malaysia became legally a 
federal state in 2018 but is still considered to be in transition. It may be that it is too soon for there to be evidence on this transition.

\section{Nepal}

Nepal transitioned to a federal government system in 2015 with seven newly created provinces and 753 local governments (Vaidya et al, 2019). Devolution of responsibilities in the health sector to district level in Nepal began in 1999 with the Local Self Governance Act (LSGA) (Gurung, 2011). The first Constituent Assembly was elected in 2008 initiating wide national debate on transition to a federal system (NIRT, 2016).

\section{Health}

The national health policy in 2019 mandates subnational governments to deliver basic healthcare services including preventive and promotive care related to reproductive, maternal, child health and nutrition (Vaidya et al, 2019). To ensure that health was not de-prioritised in the federal system the government channelled the health sector budget under a conditional grant so that delivery was uninterrupted (Thapa et al, 2019).

Thapa et al. (2019) identify the major challenge during transition to be that of ensuring supplies of medical commodities and uninterrupted services. The authors suggest scaling up the ability of local bodies to manage drug procurement and general logistics and ensure adequate human resources in local healthcare centres. Health personnel at local level are primarily trained to offer services and lack skills on management and procurement. For a successful federally governed health sector a legislative framework still needs to be in place.

In 2012 the Government of Nepal commissioned a review of health sector functions and their assignment to levels of government in anticipation of a federal system being introduced (Barker, 2012). The report recommends a slowly phased transition to allow for changes and adjustments to be made. It recommends "that the changeover be facilitated by augmenting the existing responsibilities at the regional level under the present system (Nepal is currently split into five administrative regions), to provide the opportunity for officials to gain wider experience and for them to better understand the new demands that will be placed on them under a new federal system." (Barker, 2012: pp. 2-3). There are also recommendations for a communication strategy and management of change with a designated Ministry of Health and Population (MOHP) office for oversight of the transition. Principles are outlined for identifying all of the functions of the MOHP and how those functions should be assigned. The report concludes with a suggested allocation of health functions between central, federal provincial, and local district level government.

A 2011 paper identifies bottlenecks to health sector decentralisation in Nepal suggesting lack of: clear cut policy, elected bodies, and coherence in the capacity building process of local bodies (Gurung, 2011). The author also identifies poor: coordination among sectors, handover processes, and selection process of management committees. Delays are also caused by debate about state restructuring and different political ideologies on decentralisation.

Sharma et al. (2018: p. 1147) suggest that negotiating the tiers of federalism presents an opportunity for the Ministry of Health to pioneer "governance and regulation by setting standards, 
producing guidelines, ensuring best practices, and strengthening the quality and costeffectiveness of services offered by the health system".

\section{Education}

Education was largely centralised in Nepal until the new constitution in 2015, unlike the health sector which had undergone various levels of decentralisation. The constitution devolved primary and secondary education to provincial and local levels (Shangraw, 2019). The constitution describes which type of education falls under which jurisdiction but only broadly how federalism should be implemented (NIRT, 2016). The transfer of power has been slow and with lack of coordination between government levels and delays in passing policies in the national parliament. There have been issues between federal and local levels (Shangraw, 2019).

An unpublished student paper reports on interviews with government officials, teachers and stakeholders on the transition to federal education policy (Shangraw, 2019). The research finds general optimism for the federal transition but capacity is lacking at the local level and old institutions persist. The goals of local democracy are particularly limited in mountainous areas of Nepal. A blog on federal decentralisation of education in Nepal highlights the issue of devolving responsibility to ill-equipped local bodies (Uprety \& Bhatta, 2018).

A Nepal education sector analysis states that "transition to a federal system of governance presents an opportunity to overhaul the system, structure, and role capacity of the school sector to maximize its effectiveness, efficiency, and ability to improve equitable access to quality education for all" (NIRT, 2016: p. ix). The constitution establishes a vision of rights-based education but needs laws and policies that enforce them.

The United Nations Educational, Scientific and Cultural Organization (UNESCO) set up a Federalism and Education Support Group (FESG) in their Kathmandu office (NIRT, 2016).

The Nepal National Institute for Training and Research (NIRT, 2016) suggested planning for the following as important for moving forward to a federal structure:

- Free and compulsory education as a shared responsibility of federal, provincial, and local government structures.

- Regulation and management of private schools.

- Address issues of language of instruction in a federal Nepal.

- Ensure equitable access for all.

- Define modalities of teacher recruitment and appointment in the federal structure.

- Outline how finances should be distributed equitably at the federal, provincial, and local levels.

Priority considerations for capacity building in the NIRT sector analysis include "Developing clear professional profiles and recruitment criteria to ensure that staff in the provincial and districts levels have the competencies necessary to fulfil their duties successfully" (NIRT, 2016: p.91).

UNESCO (2014) put together a number of discussion papers to reflect on the experiences of other federal countries and offer practical recommendations. The papers include: 
- A mapping of ongoing initiatives in Nepal and noting the degree of decentralisation of education planning and provision. It identifies a gap in the debate with regard to how finances and resources will be equitably distributed across states and local governments.

- A comparative study looks at the role of federal government in education in Bangladesh, Pakistan, India, South Africa, Australia, Canada, and the USA. The main issue identified in the process of restructuring was where there was multilingual, multicultural and multiethnic background of students. The paper offers a framework for the responsibilities of different levels of stakeholders assuming that the state government will be more powerful than the 'federal/central' government.

- A third paper looks at teacher management and development in a federal system. It suggests that local bodies should be able to recruit teachers that are certified by the Teacher Service Commission and that central government should provide standards for teacher management. It recommends that the constitution incorporate a separate section or articles on education, particularly to ensure that it is free for all.

- The fourth paper argues that to ensure free and compulsory education the central government should develop a broad policy frame and then the state or province should consider the socio-economic and cultural factors for effective implementation.

- A further paper discusses financing underlining the need to restructure the educational institutions following the restructuring of the state. And suggests a need for public sector finance reform.

- The sixth paper in the collection discusses different layers of governance and emphasises the need for capacity building in all levels.

A review of education in Nepal in April 2018 from the World Education News and Reviews describes the federal system as "conflict-ridden and slow-moving process fraught with setbacks and delays" (Dilas et al., 2018: p.1). With not all local governments fully functional, education is largely under the previous system where the Ministry of Education oversees five regional districts.

Interviews with education stakeholders in 2018 identified a lot of uncertainty around public administration processes (Daly et al, 2020). Respondents were optimistic about opportunities for improvement in education quality within the new structure. Sustaining existing local partnerships was seen as important whilst going through the transition and avoiding patronage politics. The research concludes that there is political will to support federalisation but insufficient legislative and regulatory frameworks.

\section{Indonesia}

There was not scope in this report to explore the government of Indonesia structure but it has been described in the literature as "quasi-federal" (e.g. Sung \& Hakim, 2019; Bertrand, 2007). The term 'federal' is not used in the literature regarding health and education governance in Indonesia. Search results on decentralisation reported in this section may offer lessons.

An article on decentralisation and functional assignment for Indonesia's health and education services finds that, despite deconcentration reforms, central government remain the dominant 
actor with regards to service delivery (Purwanto \& Pramusinto, 2018). Local governments have been allocated functions but not given the budget to carry them out.

\section{Health}

Decentralisation in the health sector in Indonesia began in 1991 with public hospitals given authority to manage their own human resources, finances, and procurement (Maharani et al., 2015). Paramita et al (2018) explore health care equality in the country stating that Indonesia has been decentralised since 2001.

Paramita et al. look at distribution trends across 34 provinces and find greater inequality in the distribution of physicians and hospital beds since decentralisation. However, the distribution of community health centres has improved. The authors recommend that although there is local autonomy for the development of health resources, national government should monitor nationwide distribution and advise local governments.

A systematic review of the impacts of decentralisation of the health system in Indonesia highlights problems in three of the World Health Organisation six building blocks ${ }^{1}$ : service delivery, health financing, and workforce (Rakmawati, 2019). Significant inequity was found in child immunisation provision and low quality of birth assistance. Health community workers were insufficient in number and poorly distributed. Essential medicine access is a problem and there are widespread budget constraints.

Kristiansen \& Santoso (2006) look at the impacts of regional autonomy on health service provision in Indonesia. They identify lack of accountability and transparency within local administration of health services. Health centres have been turned into 'profit centres' and private sector actors are neglecting preventive care and services for the poor.

Bintang et al. (2019) explain the need for the implementation of decentralization of Indonesia's social health insurance. Regional autonomy is said to be weak in practice as the Act on National Social Security System (ANSSS) is inconsistent with the 1945 Constitution. The Constitution, Acts, and current laws need to be in alignment.

\section{Education}

As with the health sector, decentralisation in the education sector has been found to have created inequalities in service provision. Winardi (2017) identified gaps between regions in resources (including teachers, budgets, and facilities), school participation, and literacy. Rahman (2019) finds the decentralised system to consist of uneven teacher quality and low levels of commitment among teaching and managerial staff suggesting a need to focus on continual teacher education and training.

Aziz (2017) highlights areas of need for implementation of decentralisation of education in Indonesia such as adapting curriculum to suit regional employment needs, prioritisation of human

\footnotetext{
${ }^{1}$ https://hssfactsheets.weebly.com/uploads/4/8/1/1/48110245/gavi_cso_fact_sheet_no_5_building_blocks.pdf accessed 25.6.21
} 
resource investments, some standardisation of budget allocation for equity, and authority for laws on regional autonomy.

\section{References}

Aziz, S.L. (2017). Review On Decentralization Of Education In The Era Of Regional Autonomy In Indonesia. International Journal of Scientific \& Technology Research Volume 6, Issue 10, October 2017. https://www.ijstr.org/final-print/oct2017/Review-On-Decentralization-OfEducation-In-The-Era-Of-Regional-Autonomy-In-Indonesia.pdf

Barker, C. (2012). Analysis of health sector functions and their assignment to levels of government. A methodological review for the Ministry of Health and Population. Nepal Health Sector Support Programme.

http://www.nhssp.org.np/NHSSP_Archives/health_policy/Federal_structures_review_april 2012.pdf

Bertrand, J. (2007). Indonesia's quasi-federalist approach: Accommodation amid strong integrationist tendencies. International Journal of Constitutional Law, 5(4), 576-605. https://academic.oup.com/icon/article/5/4/576/704312

Bintang, S., Mujibussalim, M., \& Fikri, F. (2019). Decentralization of Indonesia social health insurance. International Journal of Law and Management.

https://www.emerald.com/insight/content/doi/10.1108/IJLMA-07-2018-0143/full/html

Bossert, T. J., \& Beauvais, J. C. (2002). Decentralization of health systems in Ghana, Zambia, Uganda and the Philippines: a comparative analysis of decision space. Health policy and planning, 17(1), 14-31.

https://academic.oup.com/heapol/article/17/1/14/652233?login=true

Daly, A., Parker, S., Sherpa, S., \& Regmi, U. (2020). Federalisation and education in Nepal: contemporary reflections on working through change. Education 3-13, 48(2), 163-173. https://www.tandfonline.com/doi/abs/10.1080/03004279.2019.1599408

Dilas, D.B., Cui, J., \& Trines, S. (2018). Education in Nepal. Education System Profiles. World Education News and Reviews. https://wenr.wes.org/2018/04/education-in-nepal

Gurung, G. (2011). Nepal health sector decentralization in limbo: what are the bottlenecks. Nepal Med Coll J, 13(2), 137-9.

https://www.researchgate.net/publication/221860345_Nepal_health_sector_decentralizati on_in_limbo_what_are_the_bottlenecks

Maharani, A., Femina, D., \& Tampubolon, G. (2015). Decentralization in Indonesia: lessons from cost recovery rate of district hospitals. Health policy and planning, 30(6), 718-727. https://academic.oup.com/heapol/article/30/6/718/734314

Kristiansen, S., \& Santoso, P. (2006). Surviving decentralisation?: Impacts of regional autonomy on health service provision in Indonesia. Health Policy, 77(3), 247-259. https://www.sciencedirect.com/science/article/abs/pii/S0168851005001806 
NIRT (2016). Nepal education sector analysis. National Institute for Research and Training (NIRT) \& American Institute of Research (AIR). Kathmandu, Nepal.

https://www.globalpartnership.org/sites/default/files/2019-05-nepal-education-sectoranalysis.pdf

Paramita, S. A., Yamazaki, C., Setiawati, E. P., \& Koyama, H. (2018). Distribution trends of Indonesia's health care resources in the decentralization era. The International journal of health planning and management, 33(2), e586-e596.

https://pubmed.ncbi.nlm.nih.gov/29527720/

Purwanto, E. A., \& Pramusinto, A. (2018). Decentralization and functional assignment in Indonesia: the case of health and education services. Policy Studies, 39(6), 589-606. https://www.tandfonline.com/doi/abs/10.1080/01442872.2018.1530413?journalCode=cpo s20

Rahman, A. A. (2019). Decentralised Education Policy in Indonesia: Intended Outcomes and Remaining Challenges for Teachers. Exchanges: The Interdisciplinary Research Journal, 6(2), 30-47. https://exchanges.warwick.ac.uk/index.php/exchanges/article/view/240

Rakmawati, T., Hinchcliff, R., \& Pardosi, J. F. (2019). District-level impacts of health system decentralization in Indonesia: A systematic review. The International journal of health planning and management, 34(2), e1026-e1053.

https://pubmed.ncbi.nlm.nih.gov/30901111/

Shangraw, J. (2019). Local Democracy and Education Policy in Newly Federal Nepal. College of William \& Mary International Relations.

https://digitalcollections.sit.edu/cgi/viewcontent.cgi?article=4206\&context=isp_collection

Sharma, J., Aryal, A., \& Thapa, G. K. (2018). Envisioning a high-quality health system in Nepal: if not now, when?. The Lancet Global Health, 6(11), e1146-e1148.

https://www.thelancet.com/journals/langlo/article/PIIS2214-109X(18)30322-X/fulltext

Thapa, R., Bam, K., Tiwari, P., Sinha, T. K., \& Dahal, S. (2019). Implementing federalism in the health system of Nepal: opportunities and challenges. International journal of health policy and management, 8(4), 195.

http://www.ijhpm.com/article_3579_efbd5a429ffb7cc9b002da8fd85fb0e7.pdf

UNESCO (2014). A Resource material on education and federalism in Nepal. https://unesdoc.unesco.org/ark:/48223/pf0000230932

Uprety, L. \& Bhatta, P. (2018) The State and the School: Federal decentralisation of education in Nepal. Blog accessed 22.6.21. https://www.unite4education.org/global-response/thestate-and-the-school-federal-decentralisation-of-education-in-nepal/

Vaidya, A., Simkhada, B., \& Simkhada, P. (2019). The Impact of Federalization on Health Sector in Nepal: New Opportunities and Challenges. Journal of Nepal Health Research Council, 17(4), 558-559.

http://eprints.bournemouth.ac.uk/33273/1/The\%20\%20Impact\%20\%20of\%20\%20Federal ization\%20\%20on\%20\%20Health\%20\%20Sector\%20\%20in\%20\%20Nepal.pdf 
Winardi, W. (2017). Decentralization of Education in Indonesia-A Study on Education

Development Gaps in the Provincial Areas. International Education Studies, 10(79), 105539. https://files.eric.ed.gov/fulltext/EJ1146503.pdf

\section{Suggested citation}

Bolton, L. (2021). Transition to federal health and education governance. K4D Helpdesk Report 1024. Brighton, UK: Institute of Development Studies. DOI: 10.19088/K4D.2021.096

\section{About this report}

This report is based on six days of desk-based research. The K4D research helpdesk provides rapid syntheses of a selection of recent relevant literature and international expert thinking in response to specific questions relating to international development. For any enquiries, contact helpdesk@k4d.info.

$K 4 D$ services are provided by a consortium of leading organisations working in international development, led by the Institute of Development Studies (IDS), with Education Development Trust, Itad, University of Leeds Nuffield Centre for International Health and Development, Liverpool School of Tropical Medicine (LSTM), University of Birmingham International Development Department (IDD) and the University of Manchester Humanitarian and Conflict Response Institute (HCRI).

This report was prepared for the UK Government's Foreign, Commonwealth and Development Office ( $F C D O)$ and its partners in support of pro-poor programmes. Except where otherwise stated, it is licensed for non-commercial purposes under the terms of the Open Government License v3.0. K4D cannot be held responsible for errors, omissions or any consequences arising from the use of information contained in this report. Any views and opinions expressed do not necessarily reflect those of FCDO, K4D or any other contributing organisation.

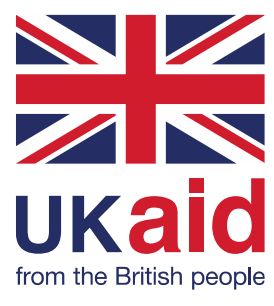

(c) Crown copyright 2021. 